\title{
Research on Construction of College Students' Social Practice Base
}

\author{
M.H. HOU, A.S. ZHANG, M.M. LUO and M. ZHAO \\ Student Affairs Office of School of Transportation Science and Engineering, Harbin Institute of Technology, \\ Harbin 150090, P.R. China
}

\begin{abstract}
College students' social practice is a college student understanding society, the national condition in practice, growth ability, contributing to society, exercise perseverance, the effective ways to cultivate character. College students' social practice base is the necessary premise of social practice smoothly, is to expand practical results, accumulated practical experience of social conditions. To make the college students' social practice scientific, standardized and institutionalized and scale, the benign social practice base construction is imperative. This article advances some views on how to build a good social practice base.
\end{abstract}

KEYWORD: College students' social practice; Base construction

\section{INTRODUCTION}

"The central committee of the communist party of China, the state council on further strengthening and improving ideological and political education of opinion" pointed out that, "Social practice is an important part of the ideological and political education, to promote college students to understand national conditions, and social growth, contributing to society, exercise ability, training quality, strengthen social responsibility have an irreplaceable role."

In the eyes of many people, it seems that got into university entered into a "greenhouse". Actually otherwise, the influence of change of social history, has been to a variety of ways to advance into the campus. Impact and influence of economic globalization, cultural diversity, severe employment situation, complicated interpersonal relationship, all make university students grow environment more complex. A beam of greenhouse cultivation is the key to the real talent can only grow in experience wind and rain. Out of the "greenhouse", in the long practice of education, talent, learn to self-reliance and self-improvement, live and work independently, only in this way, can adapt to the fierce competition in modern society.

College students' social practice is the organized, in a planned way let college students contact with the social from all walks of life, to participate in social, political, cultural, economic and other activities, so as to achieve social, know self, consolidate the book knowledge, enhance the practical ability, change ideas, at the same time, in the service of society's goals. To strengthen college students' social practice work, deepen the social practice, is not only the objective requirement of economic and social development in colleges and universities, is also an effective way to education combined with production practice, to cultivate the students' comprehensive quality, realize the comprehensive development of students, it is of great significance. College students' social practice base is the important carrier of college students' social practice activities. The stand or fall of base construction is the key to social practice can develop smoothly.

\section{DISCUSSION}

\subsection{A value, analysis of college students' social practice base construction}

After years of exploration, college students' social practice has been from the spontaneous, decentralized, conceptions of practice developed into an organized, planned, centralized bases practice; indepth development of the social practice has played a positive role. Proved that the stable and healthy practice base to make scientific, standardized and institutionalized social practice and scale, and is beneficial to practical results of application and popularization, to practice the theory of innovation and development, is conducive to the summary of practical experience and accumulation, this is a targeted in-depth and lasting and effective to carry 
out the social practical activity of a guarantee, is to adapt to the social practice requirement of the development of socialization and specialization. At the same time under the condition of the employment situation is increasingly serious, benign practice base can get through the employment of students and social barriers broaden the employment channels, increase employment opportunities.

\subsection{Clear the basic principles of college students' social practice base construction}

College students' social practice base construction work is the college students' social practice activities to effectively carry out the necessary conditions for a long time. In terms of current situation, the college students' social practice base construction is not perfect, need to further strengthen the construction. So we should increase the intensity of base construction, continuously strengthen the base function, the function can get give full play to the practices and educating people. In general, choose base should follow the following three basic principles:

A. Always carry out the principle of "mutual benefit and reciprocity, both sides benefit", to mobilize the enthusiasm for the purpose of both schools and base. Schools can use the limited funds, with the aid of base to exercise the student, and examine whether the training of talents to adapt to the needs of the society. Accept the base of practice can help students practice, solve the technical problems in production and work, training of relevant personnel, improves the production efficiency. The base of mutual benefit and win-win relationship with education in colleges and universities is the important precondition for college students practice base construction for the long-term development is the college students' social practice under the condition of market economy of the new demands, is the key to deepen college students' social practice work development.

B. The principle of colleges and universities teaching, scientific research level. Classroom teaching emphasizes on imparting scientific and cultural knowledge and easy to cause students weariness, influence the teaching quality. And college students' social practice activities to guide students to combination of theory and practice, can greatly arouse the students' interest in learning, arouse the enthusiasm of students learning, improve their ability to analyze problems and solve problems, make up the lack of classroom teaching, the school teaching quality will be improved accordingly. At the same time, the scene of the practice base of production, which is beneficial to find enterprise organization or technical problems existing in the production process, easy to find out valuable scientific research project or research direction, and according to the research team need to form a reasonable knowledge structure, make the technical problem solved. This not only can bring economic benefits to the enterprise, but also can improve the level of scientific research in the school.

C. To improve the general principle of youth students' comprehensive quality. At present college students are mostly only children, they are widespread self-consciousness is stronger, the disadvantage of social consciousness is relatively weak. They often pays attentions to individual character are very independent, and neglect the needs of the society. Many students from the practice cause. Nowadays, aims high do not meet the needs of the society. This requires colleges and universities must put students in society to exercise, make the students to overcome their own is not enough, as soon as possible familiar with the society, to adapt to the society. However, the impact of social environment for students to duality. Good environment can make students towards the direction of health; Negative environment will give a negative impact on students, is not conducive to the development of students. Therefore, the construction of the college students' social practice base to beneficial to the improvement of the students' healthy growth and comprehensive quality for the principle.

\subsection{Establish long-term effective mechanism of college students' social practice base}

College students' social practice base construction should be based on the principle of "win-win", after discussion and negotiation in the form of agreement to determine their respective in base construction, must has the responsibility and obligations, and become the basis of related activities. In fact, quite a number of social practice base construction agreement, or the agreement content is too simple, the two sides of their respective duties and obligations is not clear. On the one hand, the only known to send students school holidays to practice base, seldom care about base construction, the condition of the knowledge base in place or not on own initiative units have what problem need to help solve. Base, on the other hand, in a place or unit, the arrangement of college students' social practice often go through the motions, perfunctory, and what exactly service for college students don't too care about or know very little about. Prompting the mutual inductance irresponsible, the college students' social practice base construction lost. And so on the base construction, the school must establish a long-term mechanism, clear their responsibility and obligation, and form a written agreement, the social practice for college students and the guidance of the base construction as a job to pay special attention to this unit, emphasizing. 
Facts have proven that only form agreement, responsibilities and obligations of both parties in the construction of base to have certain binding, base construction can fall on feet. The school shall, first of all, strict performance of the agreement, the agreement provisions specified in the relevant technical guidance and the content of the aspects such as personnel, as long as each other's request, the university should give full support. At the same time, carefully organize every base practice, elaborate each work, provided a basis for the next practice, create conditions for the long-term development of the college students' social practice base. Incentives in addition, the school should also base, the base of the relevant personnel to be college students' social practice guidance teachers or adviser, ask them to lecture and do report for college students and growing base of education consciousness and sense of responsibility. At the end of the annual base for college students' social practice, for some good base and the base guide teacher should carry on the recognition and reward. Only fully arouse the enthusiasm of school and base on both sides, make joint efforts to regularly check the status of their duties and obligations and put themselves in each other, to build a base for college students' social practice activity of long-term mechanism.

\subsection{College students' social practice base construction should be developed towards diversification}

College students' social practice work after 10 years of development, job content has become increasingly rich and diverse, through the theoretical preaching, theatrical performances, agricultural technology, teaching literacy, health care services, legal speaking, environmental protection, social investigation methods such as win high visibility and reputation in society. In terms of activity time, college students' social practice work from the past to the practice of centralized, periodic, winter and summer vacation become a year-round, nationality is wide, high participation of routine activities. With the development of college students' social practice work, the original single base type is not able to meet the needs of young students to participate in social practice activities, the diversified development of college students' social practice base is imperative.

According to the practice of existing content, according to the following three kinds of college students' social practice base construction, at the same time according to the needs of students and the contents of the social practice of expanded to enrich the base type, to develop in the direction of diversification, to meet the requirements of college students' social practice long-term, whole-staffparticipation:
A. Diathesis developing base class. This kind of practice base mainly focus on college students' knowledge of the application of comprehensive ability of exercise and the comprehensive quality of ascension. Roughly divided into two aspects:

a)Applied knowledge base. Emphasis on college students apply professional knowledge to social practice, "a program under which officials" activities such as college students, teaching, for the enterprises and institutions to provide technical, consulting, training services, promote students to put the knowledge into productivity.

b)Entrepreneurial base. Focus on the students' comprehensive ability and quality, students in the base of the entrepreneurial directly put the knowledge into wealth, its practice for a long time and has the certain difficulty, with different degrees of risk, higher requirements for the various aspects of college students.

B. Service class base. This type of base require students to have certain dedication, to student's professional and ability request is not high, the practice time has certain periodicity, the difficulty of the practice is not too big. Youth volunteers, support of primary and secondary schools, trainee employment, college students "into the community volunteer service" is the typical representative of this kind of practice base, students in the service society, the practice of his own ideas, to shape their characters, and in the service of society life of truth, to seek their own value realization in service.

C. The education base class. Education for base, such as the fundamental purpose, students through this kind of base, in the form of survey, visit, visit, to know the society and society, the rich perceptual knowledge, thus to have objective and profound understanding of social each aspect, in order to set up the correct world outlook. "The three represents" the practice line, such as special investigation and belong to this kind of practice base.

\section{CONCLUSION}

With the development of The Times, there will be more forms of social practice base, the content of the college students' social practice work will be richer, and college students in practice of the effect will be more obvious. Only realize the college students' social practice base, to overcome the blindness of education, the practice of randomness. Through the base to establish the combination of teaching, scientific research, production operation mechanism, make the practice really become the important link of education to improve comprehensive quality of college students. We believe that, with the deepening understanding of the importance of job of college students' social practice, college students' social practice base construction will be able to get a new 
development; college students' social practice base will play a more important role in the practice.

\section{REFERENCES}

[1] Yu, P.L. How to construct the multi-dimensional System of social practice. China Electric Power Education: 2009(1):127-128.

[2] Zhang, W. \& Li, C.T. Construction the Quality Standard and Evaluation Mechanism of College Student's Social Practice. Physics Procedia: 2012(25): 2287-2290.
[3] Yang, H. Analysis on Policies Transformation in College Students Social Practices after Opening and Reforms in China. Studies in Sociology of Science: 2014(5):46-50.

[4] Zhou, Q. \& Liu, C. The Exploration of the Students' Social Practice and Innovation in Colleges for Electrical Engineering. Advanced Materials Research, 2014 (926): 4661-4664.

[5] Zhang, S. Z. Research on Outward-Bound to Improve College Students' Social Adaptation Ability with AQ as the Mediating Effect. Advanced Materials Research: 2014 (971): 2611-2616. 